\title{
THE EFFECT OF CURING CONDITIONS ON THE PHYSICAL PROPERTIES AND CROSSLINKING STRUCTURE OF COTTON FABRICS TREATED WITH DIMETHYLOL ETHYLENEUREA*
}

\author{
By Meng-Shung Yen and Cheng-Chi Chen \\ (Dept. of Textile Engineering and Technology, \\ National Taiwan Institute of Technology, Taipei, R.O.C.)
}

\begin{abstract}
The effect of the curing conditions on the physical properties and the crosslinking structure of cotton fabrics treated with dimethylol ethylene urea was studied.

The dry crease recovery angle (DCRA) was related to not only the product of the root of the crosslinking length and the number of crosslinks, but also the degree of the completion of crosslinkage. It was also substantially affected by the hydrogen bond effect. Wet crease recovery angle (WCRA) was related to the product of the crosslinking length, the number of crosslinks, and the degree of the completion of crosslinkage. WCRA was also affected by the fiber's swelling property. In addition, the strength loss was found to be caused by the degradation of cellulose molecules, and the stiffness formed by crosslinkage. This strength loss caused by the stiffness was related almost linearly to the product of the number of crosslinks and the degree of the completion of crosslinkage in all curing conditions.
\end{abstract}

\section{INTRODUCTION}

In previous studies, ${ }^{1,2)}$ we found that the physical properties of durable-press fabrics treated with dimethylol ethylene urea (DMEU) were closely connected with the crosslinking structure. That is to say, the dry crease recovery angle (DCRA) was related to the product of the number of crosslinks and the square root of crosslinking length; the wet crease recovery angle (WCRA) was related to the product of the number of crosslinks and the crosslinking length; and the tensile strength was approximately proportional to the number of crosslinks under a given curing temperature and curing time.

In general, the factors that affect the physical properties and the crosslinking structure of resin finished fabrics are not limited to the kinds of finishing agents. Curing condition, pre-drying

\footnotetext{
* Studies on the Durable-Press Cotton Fabrics Treated with Dimethylol Ethyleneurea Condensates (Part 3)
}

condition, and kind of catalysts are also important factors.

The effect of curing conditions on the physical properties of durable press fabrics has been widely studied. ${ }^{3-6)}$ For example, Reeves et al. ${ }^{3)}$ indicated that the state of swelling at the time of crosslinking affected the moisture regain, water inhibition, dyeability, and wet and dry recovery of treated fabrics and illustrated the hydrogen bond effect on the crease recovery angle with the diagram of hydrogen bonded crosslinks between cellulose molecules.

To understand the side effects of the crosslinkage, such as the hydrogen bond effect and swelling property, and the crosslinking structure on the physical properties of the treated fabrics, these effects must be studied separately. This paper deals with the above effects on physical properties of fabrics treated under different curing conditions. 


\section{EXPERIMENTAL}

\subsection{Procedure and measurement}

$144 \times 80 / 40^{\prime s} \times 40^{\prime s}$, plain cotton fabric was used. Dimethylol ethylene urea (DMEU) was used as finishing agent; it was synthesized by Hoover's method, ${ }^{7)} \mathrm{F}$ content/nitrogen $(\mathrm{N})$ content equaled $0.98 / 1$. Extra pure $\mathrm{Zn}\left(\mathrm{NO}_{3}\right)_{2} \cdot 6 \mathrm{H}_{2} \mathrm{O}$ was used as catalyst.

Cotton fabrics were padded with $2-8 \%$ of aqueous DMEU containing $\mathrm{Zn}\left(\mathrm{NO}_{3}\right)_{2} \cdot 6 \mathrm{H}_{2} \mathrm{O}(10 \%$ of resin concentrations) by two-dip, two-nip process (pick up, about $85 \%$ ), predried at $80^{\circ} \mathrm{C}$ for $5 \mathrm{~min}$, cured at a specified temperature and time, the treated fabrics were soaped, rinsed, and dried.

The DCRA and the WCRA of resin finished fabrics were measured by the Monsanto method, and the single yarn tensile strength (Warp) of the fabrics was measured with an Instron tester.

Infrared spectra of treated samples were measured with BOMEM Model DA3-002 by using a $\mathrm{KBr}$ disc technique. ${ }^{13)}$

\subsection{Analysis and calculation}

The amount of combined $\mathrm{F}$ in the forms of $\mathrm{N}-\mathrm{CH}_{2} \mathrm{OH}\left(F_{l}\right), \quad \mathrm{N}-\mathrm{CH}_{2} \mathrm{OCH}_{2}-\mathrm{N}\left(F_{e}\right)$, Cell$\mathrm{OCH}_{2}-\mathrm{N}\left(F_{c}\right)$ or $\mathrm{N}-\mathrm{CH}_{2}-\mathrm{N}\left(F_{m}\right)$ ( $\mu$ mole/g) structures in the finished fabrics was analyzed by the previous method. ${ }^{2,9)}$

The average crosslinking length $(n)$, the average number of crosslinks $(r)$ and the degree of the completion of crosslinkage $(\alpha)$ were calculated respectively from the following equations:

$$
\begin{aligned}
& n=\frac{F_{e} / 2+F_{m}}{\left(F_{l}+F_{c}\right) / 2}+1 \\
& r=\frac{N / 2}{n}
\end{aligned}
$$

and

$$
\alpha=\frac{F_{c}}{F_{c}+F_{l}}
$$

\section{RESULTS AND DISCUSSION}

3.1 The effect of curing conditions on the physical properties of treated fabrics

Cotton fabrics were padded with DMEU resin solutions $(2-8 \%)$ containing $\mathrm{Zn}\left(\mathrm{NO}_{3}\right)_{2} \cdot 6 \mathrm{H}_{2} \mathrm{O}$, predried at $80^{\circ} \mathrm{C}$ for $5 \mathrm{~min}$, cured at different temperatures and durations of time. Fig. 1 shows the relationship between the DCRA and the $\mathrm{N}$ content of the finished fabrics. It is found that a higher curing temperature or a longer curing time result in a higher DCRA at the same $\mathrm{N}$ content. Fig. 2 shows the relationship between WCRA and $\mathrm{N}$ content. The influence of curing

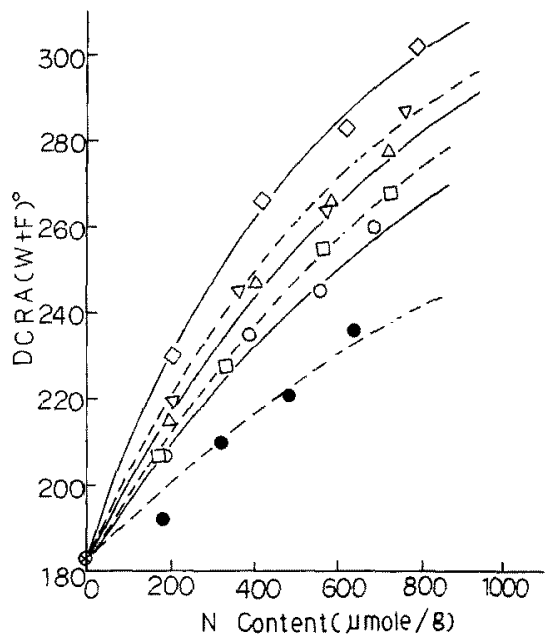

Fig. 1 Changes of DCRA against $N$ content of DMEU treated fabrics under different curing conditions.

Samples are all pre-dryed at $80^{\circ} \mathrm{C}, 5 \mathrm{~min}$.

(O) $110^{\circ} \mathrm{C}, 3 \mathrm{~min} \quad(\nabla) 150^{\circ} \mathrm{C}, 2 \mathrm{~min}$

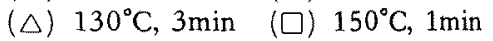

(১) $150^{\circ} \mathrm{C}, 3 \mathrm{~min}$ (ब) pre-dry only

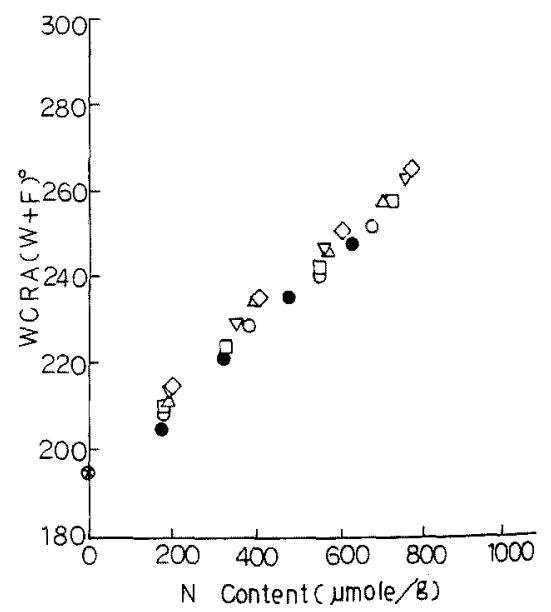

Fig. 2 Changes of WCRA with the N content of DMEU treated fabrics under different curing conditions.

The conditions and symbols are the same as described in Fig. 1. 
conditions on WCRA is not as great as that on DCRA. It indicates that a higher curing temperature or a longer curing time improves the DCRA considerably, but improves the WCRA in an insignificant manner.

In general, the strength loss is closely related to the crease recovery angle of the finished fabrics. The relationship between the improvement of dry crease recovery angle ( $\triangle \mathrm{DCRA}$ ) against the loss of strength ( $S L$ ) was plotted (Fig. 3). The strength loss increases with the $\triangle D C R A$ under the same curing condition. However, the loss of strength under the same $\triangle D C R A$ changes with curing conditions: the higher the temperature or the longer the time, the larger the strength loss. Two main reasons for strength loss of resin-finished fabrics were suggested. ${ }^{8}$ ) One was the stiffness of fabrics, which was attributable to crosslinkage formed between cellulose molecules, and the other was the degradation of cellulose molecules caused by curing with acid catalyst.

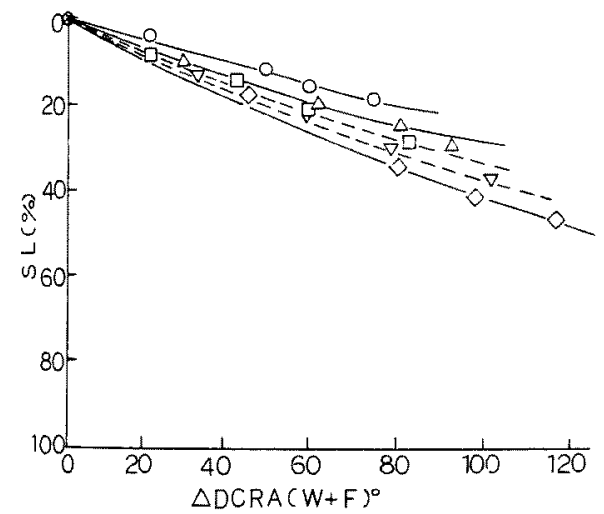

Fig. 3 Changes of strength loss against $\triangle \mathrm{DCRA}$ of DMEU treated fabrics under different curing conditions.

The conditions and symbols are the same as described in Fig. 1.

The above effects of curing conditions on the physical properties can be explained as mainly due to the factors of crosslinking structure and the side effects of the hydrogen bond and the swelling, which are influenced by crosslinkage in the finished fabrics.

\subsection{The effect of curing conditions on the crosslinking structure}

We had studied the relation between the curing condition and the crosslinking structure for rayon, mercerized cotton and cotton fabrics treated with DMEU under various conditions of curing time, temperature and catalysts. ${ }^{9}$ ) Here, we further studied the effect of curing conditions on crosslinking structure by changing the resin concentration and substituting the process of pad-cure with pad-dry-cure.

By using the various combined amount of the $F$, we calculate the $n, r$ and $\alpha$ of treated fabrics with equations (1), (2) and (3), and the results are shown in Fig. 4. It is found that a longer curing time and a higher curing temperature result in shorter crosslinking length and more number of crosslinks and the finished fabrics have a longer crosslinking length when the finishing is proceeded by pre-dry only. This is because a higher curing temperature causes a larger decomposition of $\mathrm{N}-\mathrm{CH}_{2} \mathrm{OCH}_{2}-\mathrm{N}$ into $\mathrm{N}-\mathrm{CH}_{2}-\mathrm{N}$. Fig. 4 also shows that the resin concentration affects $n$ and $r$ considerably. The reason why resin concentration greater than $4 \%$ resulting in $n$ 's rapid increase and $r$ 's slow increase had been explained by the rapid increase of interreaction between DMEU. ${ }^{2)}$
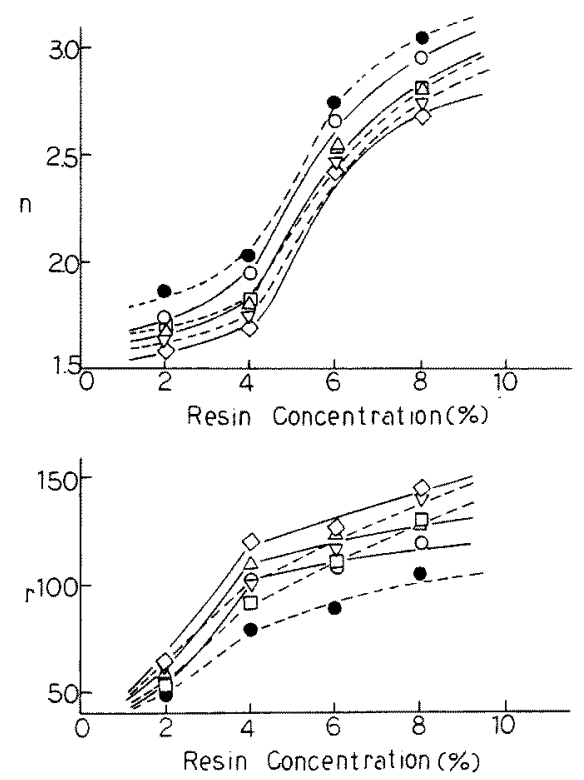

Fig. 4 Plot of $n$ and $r$ of fabrics treated under different curing conditions against DMEU concentration.

The conditions and symbols are the same as described in Fig. 1. 
3.3 The effect of crosslinking structure on physical properties under different curing conditions

We found the equation (4) for DMEU finished fabrics. ${ }^{2)}$

$$
\text { DCRA }=K_{\mathrm{D}_{1}^{\prime}} r \sqrt{n}+K_{\mathrm{D}_{0}}
$$

where $K_{\mathrm{D}_{1}}$ and $K_{\mathrm{D}_{0}}$ are constant at the same curing condition. We also explained that the effects of the number of crosslink and the crosslinking length on the crease recovery angle of treated fabrics were attributed to a drawing effect and a supporting effect respectively. Here, we further study the effect of curing conditions on the above relationship.

Fig. 5 shows the relationship between the DCRA and $r \sqrt{n}$ of cotton fabrics cured in various curing temperatures and durations of time. From Fig. 5, it is found that equation (4) can satisfy every curing condition, but the higher the curing temperature and the longer the curing time, the larger the $K_{\mathrm{D}_{1}^{\prime}}$ (from the slope).

In order to study the factors which may affect $K_{\mathrm{D}_{1}^{\prime}}$, we consider the effect of the degree of the completion of crosslinkage $(\alpha)$ and substitute the horizontal axis of Fig. 5 with $r \sqrt{n} \alpha$ as shown in Fig. 6. It is found that the relation between DCRA and $r \sqrt{n} \alpha$ are straight lines and these lines are all parallel for every curing temperature and time. This fact clearly shows that the effect of curing temperature and time on $K_{\mathrm{D}_{1}}$ is due solely to the degree of the completion of crosslinkage. As the degree of the completion of crosslinkage does not greatly change under a given curing condition, the equation (4) also satisfies as stated in the previous paper. ${ }^{2}$ ) Therefore, we can further conclude that the following equation (5) can be obtained.

$$
\mathrm{DCRA}=K_{\mathrm{D}_{1}} r \sqrt{n} \alpha+K_{\mathrm{D}_{0}}
$$

where, $K_{\mathrm{D}_{1}}$ is a constant in all curing conditions, and $K_{D_{0}}$ is affected by the curing temperature and time.

From Fig. 6 , the values of $K_{\mathrm{D}_{0}}$ (the DCRA values obtained from the extrapolation of the parallel lines at $r \sqrt{n} \alpha=0$ ) are increased with the elevation of curing temperature or the extension of curing time. This fact may be due to the hydrogen bond effect. Many studies ${ }^{3,11,12)}$ had

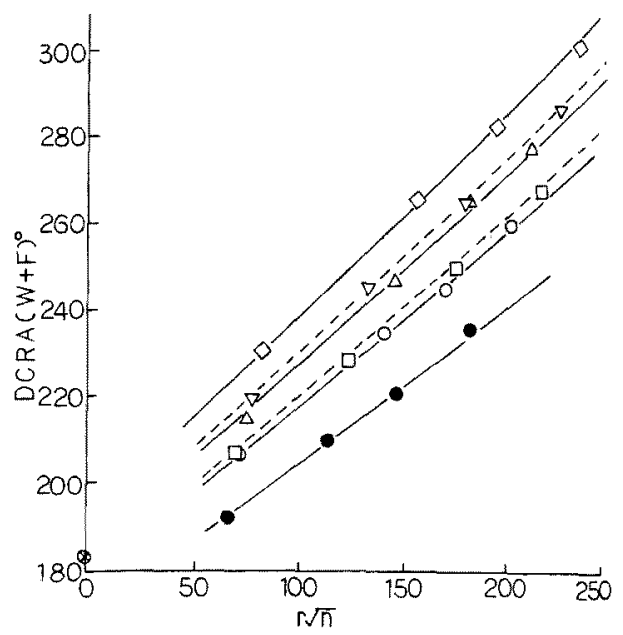

Fig. 5 The relationship between DCRA and $r \sqrt{n}$ of DMEU treated fabrics under different curing conditions.

The conditions and symbols are the same as described in Fig. 1.

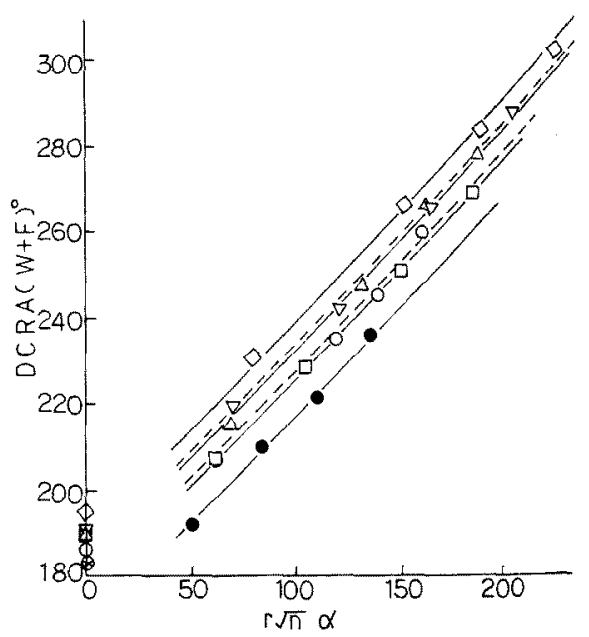

Fig. 6 The relationship between DCRA and $r \sqrt{n} \alpha$ of DMEU treated fabrics under different curing conditions.

The conditions and symbols are the same as described in Fig. 1.

suggested that the existence of hydrogen bond could affect the DCRA.

In order to confirm the hydrogen bond effect on DCRA, the fabric is treated with water instead of the crosslinking agent under various curing conditions without soaping, and the results are shown in the vertical axis of Fig. 6. It is shown 
Table 1. The IR spectra intensity ratios of various functional groups in cotton fabrics treated with DMEU under different curing conditions.

\begin{tabular}{|l|l|l|l|l|l|}
\hline $\begin{array}{l}\text { The Samples } \\
\text { ratios of } \\
\text { various functional group }\end{array}$ & Control & $(1)$ & (2) & (3) & (4) \\
\hline$\frac{\mathrm{CH}_{2} \text { bending }}{\mathrm{CH} \text { bending }}$ & 0.39 & 0.36 & 0.33 & 0.31 & 0.29 \\
\hline$\frac{\mathrm{CH} \text { bending of } \mathrm{C}_{2} \text { and } \mathrm{C}_{3}}{\mathrm{CH} \text { bending }}$ & 0.15 & 0.15 & 0.15 & 0.14 & 0.14 \\
\hline$\frac{\text { bridge oxygen vibration }}{\mathrm{CH} \text { bending }}$ & 0.24 & 0.21 & 0.21 & 0.19 & 0.17 \\
\hline
\end{tabular}

Sample (1) was predried at $80^{\circ} \mathrm{C}$ for $5 \mathrm{~min}$.

Sample (2), (3) and (4) were all predried at $80^{\circ} \mathrm{C}$ for $5 \mathrm{~min}$ and then cured at $110^{\circ} \mathrm{C}$, $130^{\circ} \mathrm{C}$ and $150^{\circ} \mathrm{C}$ respectively for $3 \mathrm{~min}$.

that the DCRAs of fabrics treated only with water for various curing conditions are similar in every $K_{\mathrm{D}_{0}}$. Table 1 shows the IR spectra of the samples from various curing temperatures (the $\mathrm{N}$ contents of all samples were about $600 \mu \mathrm{mole} / \mathrm{g}$ ). The change of ratios of the IR spectra intensity from various functional groups to $\mathrm{CH}$ group with curing temperature clearly indicates that a higher restriction occurs among intermolecules by hydrogen bond at a higher curing temperature.

The effect of curing condition on $K_{\mathrm{D}_{0}}$, therefore, can be explained by the hydrogen bond. That is, the fabrics treated at a higher curing temperature or a longer curing time will have more hydrogen bondings. Additionally, other factors, such as the distribution of resin agent, may also affect $K_{\mathrm{D}_{0}}$ under the various curing conditions.

In the previous study, ${ }^{2)}$ we also found that the relation between WCRA and $r n$ has an almost linear relation under a given curing condition. Considering the WCRA being affected by $\alpha$, we plotted WCRA against $r n \alpha$ instead of $r n$ (Fig. 7). The relation between WCRA and $r n d$ is almost linear, and the slopes of the lines decrease slightly when the curing temperature is raised or curing time increased.

Thus, the following equation can be obtained.

$$
\text { WCRA }=K_{\mathrm{w}_{1}} r n \alpha+K_{\mathrm{w}_{0}}
$$

where, the $K_{\mathrm{W}_{1}}$ decreases slightly with the elevation of curing temperature or the extention of curing time. The slight variation of $K_{\mathrm{w}_{1}}$ was also observed in the case of different length of cross-

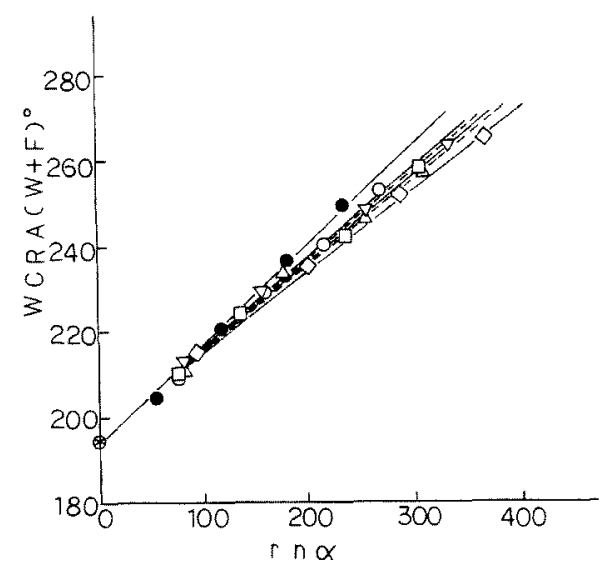

Fig. 7 The relationship between WCRA and $r n \alpha$ of DMEU treated fabrics under different curing conditions.

The conditions and symbols are the same as described in Fig. 1.

linking agent (i.e., a longer length of crosslinking agent produces a larger $K_{\mathrm{W}_{1}}$ ) in our previous study. ${ }^{2)}$ The reason may be attributed to the different swelling effect on WCRA since the WCRA is measured under the wet state.

Fig. 8 represents the plot of $K / S$ vs. $m \alpha$. It clearly shows that the $K / S$ (the dyeability of treated fabrics dyed with C. I. Direct Green 26, and we take it as an index of swelling effect caused by the crosslinkage) of a higher curing temperature is smaller than that of a lower curing temperature at the same $r n \alpha$. By comparing Fig. 7 with Fig. 8, it clearly indicates that WCRA is also affected by the swelling property of fiber 


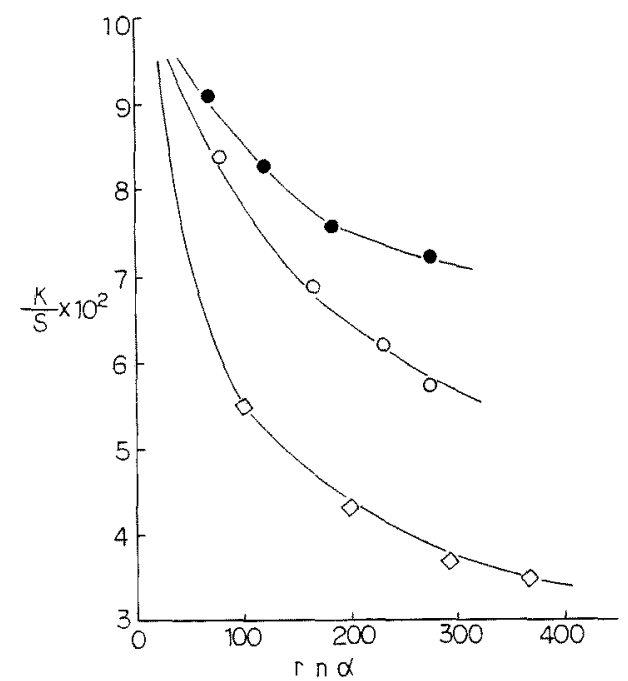

Fig. 8 The relationship between $K / S$ and $r n \alpha$ of DMEU treated fabrics under different curing conditions.

The conditions and symbols are the same as described in Fig. 1.

caused by the crosslinkage. Thus, if we were to consider the effect of swelling property on WCRA only, then a better WCRA would be obtained at a lower curing temperature, a shorter curing time, or with a longer crosslinking agent. In the earlier study of the effect of finishing process on crease recovery angle, the effect of the crosslinking structure and swelling property has scarcely been discussed separately. Reeves et al. ${ }^{3)}$ concluded that the state of the fiber swelling at the time of crosslinking had a tremendous influence on fiber structure and on the resulting physical properties of fabrics made from the fibers; a high degree of fiber swelling resulted in fabrics with better wet but little or no increase in dry crease recovery.

Fig. 9 shows the effect of curing conditions on the strength of treated fabrics. In each curing condition, the relation between the $S L$ and $r \alpha$ is almost linear, and the linear relationship deviates at higher resin concentration. Fig. 9 also shows that a higher curing temperature or a longer curing time causes an increase in $S L$ under the same $r \alpha$. This phenomenon can be attributed to the different degree of cellulose molecules degradation under different curing conditions. ${ }^{8}$ )

To study the strength loss caused by crosslinkage, the treated fabrics were hydrolyzed by

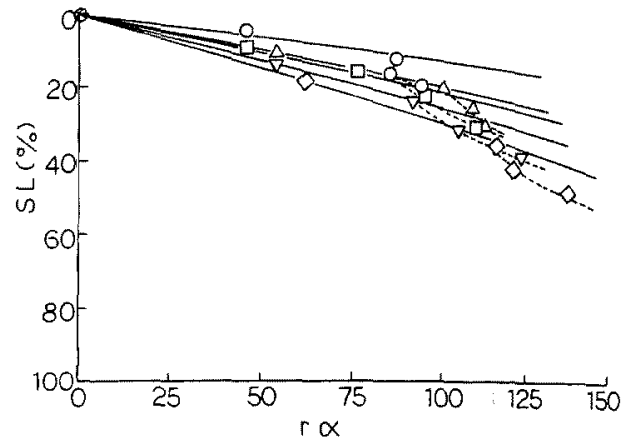

Fig. 9 The relationship between the strength loss and $r \alpha$ of DMEU treated fabrics under different curing conditions.

The conditions and symbols are the same as described in Fig. 1.

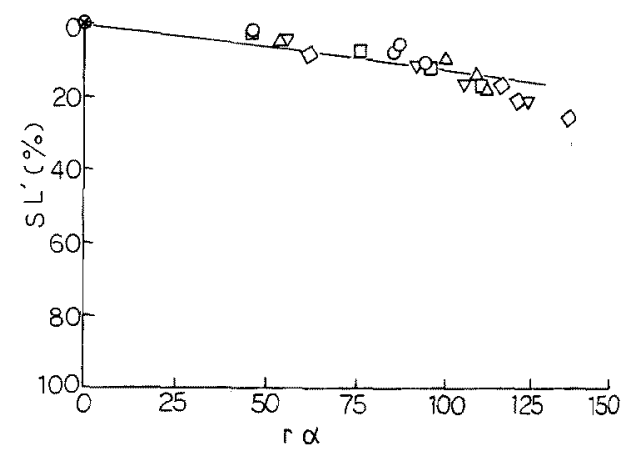

Fig. 10 The relationship between the strength loss caused by the stiffness $\left(S L^{\prime}\right)$ and $r \alpha$ of DMEU treated fabrics under different curing conditions.

The conditions and symbols are the same as described in Fig. 1.

urea-phosphoric acid method, ${ }^{10)}$ and the strength loss due to the degradation of cellulose molecule caused by the curing with acid catalyst was determined. The strength loss caused only by the stiffness from crosslinkage (SL') was obtained from the total strength loss by subtracting that by the degradation of cellulose molecule, and results were plotted in Fig. 10. A comparison of Fig. 9 with Fig. 10 shows that the $S L^{\prime}$ is related almost linearly to the product of the number of crosslinks and the degree of the completion of crosslinkage for all curing conditions. The relation can be described as equation (7).

$$
S L^{\prime}=k_{\mathrm{s}} r \alpha
$$


where, $k_{\mathrm{s}}$ is nearly constant for all curing conditions.

\section{CONCLUSION}

Cotton fabrics were treated with DMEU under various curing conditions and their physical properties were revealed as follows.

(1) A higher curing temperature or a longer curing time improves the DCRA considerably, but improves the WCRA in an insignificant manner.

(2) The longer curing time and the higher curing temperature result in a shorter crosslinking length and a larger number of crosslinks.

(3) DCRA is related to the product of the root of the crosslinking length, the number of crosslinks, and the degree of the completion of the crosslinkage in each curing condition. It is also improved by the hydrogen bond effect.

WCRA is related to the product of the crosslinking length, the number of crosslinks, and the degree of the completion of the crosslinks in each curing condition. It is also improved by the swelling effect.

(4) The strength loss caused by the stiffness is related almost linearly to the product of the number of crosslinks and the degree of the completion of crosslinkage in treated fabrics for all curing conditions.

\section{Literature}

1) M. S. Yen and C. C. Chen; J. Soc. Fiber Sci. \& Tech., Japan (Sen-i Gakkaishi), 43, 300 (1987).

2) M. S. Yen; ibid., 43, 305 (1987).

3) W. A. Reeves, R.M. Perkins, and L.H. Chance; Textile Res. J., 30, 179 (1960).

4) M. L. Rollins, J. H. Carra, E. T. Gonzales, and R. T. Berni; Textile Res. J., 36, 185 (1966).

5) R. J. Harper, Jr., J.S. Bruno, and W. A. Reeves; Textile Res. J., 38, 292 (1968).

6) A.M. Cannizzaro, W. A. Goynes, M. L. Rollins, and E. J. Keating; Textile Res. J., 40, 1087 (1970).

7) F. W. Hoover and G. T. Voala; (Du Pont) USP 2373136 (April, 10, 1945).

8) L. Segal and J.D. Timpa; Textile Res. J., 43, 185 (1973).

9) M. S. Yen and H. Tonami; J. Soc. Fiber Sci. \& Tech, Japan (Sen-i Gakkaishi), 37, T-18 (1981).

10) H. Z. Jung, K. R. Benerito, E. J. Gonzales, and R. J. Berni; Textile Res. J., 44, 670 (1974).

11) C. V. Stevens and B. F. Smith; Textile Res. J., 40, 749 (1970).

12) L. Rebenfeld, C. V. Oster, Jr., and L. F. Klurfeld; Textile Res. J., 41, 139 (1971).

13) O'Connor, Robert T., Du Pre, Elsie F., and McCall, Elizabeth R., Anal. Chem., 29, 998 (1957).

\section{ジメチロールエチレン尿素で加工した綿布に関する研究 \\ 一その橋かけ構造と物性に及ぼすキュア条件の効果 -}

国立台湾工業技術学院紻維工程技術系

顔 明雄，陳建 智

本研究はパッドードライーキュア方式を用いてDMEU で綿布を処理し，その加工布の橋かけ構造と物性に及ぼ すキュア条件の効果を检討した。

キュア条件を変えるとき，加工布の乾しわ回復角は橋 加長さの平方根と橋加けの数の皘に関係するほかに， 榞加の完成度にあ関係し，それはまた水素結合に強く 燍䈞される。一方，湿しわ回復角は橋かけ長さ，橋かけ
の数之橋かけの完成度の皘に関係し，湿しわ回復角はま た織維の膨潤性の影響を受けるととがわかった。なお， 加工布の強度低下はセルロース分子鎖の切断と橋加けに よる剛直化に基づく 2 つの原因であるが，すべてのキュ ア条件において剛直化による加工布の強度低下は橋加 の数と橋かけの完成度の積に比例するととを見い出した。 